\title{
Application Photocatalysis for Treatment of Industrial Waste Water-A Short Review
}

\author{
Ranjana Das \\ Chemical Engineering Department, Jadavpur University, Kolkata, India \\ Email: ranjanads78@gmail.com, rdasmondal@research.jdvu.ac.in
}

Received: 2 May 2014; revised 15 June 2014; accepted 25 July 2014

Copyright (C) 2014 by author and OALib.

This work is licensed under the Creative Commons Attribution International License (CC BY). http://creativecommons.org/licenses/by/4.0/

(c) (i) Open Access

\begin{abstract}
Occurrence of persistent organic compounds in industrial effluents and their efficient removal technique has emerged as a crucial problem to waste water treatment plants. This review aims to focus on the plight associated with the effluents from textile industry, agricultural and pharmaceutical effluents. The occurrence of dyes, pesticides and endocrine disrupting chemicals in aquatic ecosystems may cause chronic diseases, affect the human endocrine system and have appeared as crucial factor to consider for drinking and non-potable end uses of water. Extensive researches have been attempted to screen effective and safe method of contaminants removal by modifying conventional treatments as well as advanced processes by renowned authors. This paper aims to review different possible routes of effluent treatment emphasizing on complete mineralization of the targeted contaminants. With this purpose, a comprehensive review has been presented to deliver essential information about dealing with photocatalytic mineralization of pollutants.
\end{abstract}

\section{Keywords}

Photocatalysis, Textile Effluent, Pesticide, Waste Treatment, Endocrine Disrupting Chemical

Subject Areas: Chemical Engineering \& Technology, Environmental Sciences

\section{Introduction}

Due to an increase in human and livestock population, industrial developments have raised the concern of safe drinking water and non-potable water supply whereas, environmental protection, waste management and pollution control are also emerging for crucial problems of urbanized civilization. According to WHO and UNICEF, polluted drinking water and lack of sanitation are responsible for death of approximately 4500 - 5000 children per day, and one billion people still lack access to safe drinking water [1]. The second most critical issue is the 
disinfection of water for agricultural usage purpose. According to the Food and Agriculture Organization (FAO) of the United Nations, agricultural purposes consume $70 \%$ of fresh water used worldwide with increased over $95 \%$ of the available fresh water in developing countries [2]. Enormous ongoing researches explore innovative techniques and ideas to treat waste stream of various industrial sources. This review highlights the polluted streams of agricultural fields, textile industries, and pharmaceutical industries to critically assess all possible practices of waste water treatment for obtaining ecofriendly discharge. This review also portrays about the applicability and recent advancement of the photocatalytic process for treating industrial waste (dyes, pesticides and pharmaceutical waste). In recent years, semiconductor photocatalytic process has shown a great potential being cost effective, environment friendly and in the field of sustainable treatment technology with zero waste discharge. Photocatalysis involves removal of water contaminants that are chemically stable and resistant to biodegradation. The method offers advantage over usual wastewater treatment techniques such as activated carbon adsorption, chemical oxidation, biological treatment and membrane separation. Activated carbon adsorption involves phase transfer of pollutants without decomposition. This incomplete removal process further increases pollution load on environment. Chemical oxidation is also a cause for incomplete mineralization of organic substances with generation of undesirable toxic byproducts' complex reaction mechanism. Biological treatment faces crisis for sludge removal, for very slow reaction rate and control of proper process conditions (microbial growth condition). The setback of retentive components, severe membrane fouling and costly process setup possess a great impact on membrane process. In this context, photocatalytic processes offer a number of advantages for the removal of pollutants from water, complete mineralization, use of low cost catalyst system and comparatively trouble-free arrangement. First report on photocatalysis using $\mathrm{TiO}_{2}$ for disinfection was reported in 1985 [3]. Authors reported the inactivation of Gram-positive bacteria Lactobacillus acidophilus, a Gram-negative bacterium E. coli, Saccharomyces cerevisiae and Chlorella vulgaris with irradiated $\mathrm{TiO}_{2} / \mathrm{Pt}$ powder. The principle of photocatalysis process relies on "in-situ" generation of hydroxyl radicals under ambient conditions which are capable of converting a wide spectrum of toxic organic compounds including non-biodegradables into relatively less toxic end products such as $\mathrm{CO}_{2}$ and $\mathrm{H}_{2} \mathrm{O}$ [4]. Several authors have summarized the steps of photocatalysis reaction [5]. The semiconductor oxide (e.g. $\left.\mathrm{TiO}_{2}\right)$ under irradiation with light having energy higher than that of the band gap $(\mathrm{h} v)$, a pair of conduction band electron $\left(\mathrm{e}^{-}\right)$and valence band hole $\left(\mathrm{h}^{+}\right)$is generated (Equation (1)). After this primary event, the charge carriers either recombine with the bulk of the material or migrate to the particle surface. Some authors suggested that, two different mechanisms may take place simultaneously either they get transferred to the adsorbed pollutant causing immediate oxidation (Equation (2)), or they are first transferred to adsorbed water molecules generating hydroxyl radicals, $\mathrm{OH}^{*}$, upon which reaction with the pollutant produce the respective oxidation products (Equation (3)).

$$
\begin{aligned}
\text { Photocatalyst } & \stackrel{\mathrm{hv}}{\longrightarrow} \mathrm{e}^{-}+\mathrm{h}^{+} \\
\mathrm{h}^{+}+\text {pollutant } & \rightarrow \text {. } \text { pollutant }^{+} \\
\mathrm{h}^{+}+\mathrm{OH} & \rightarrow \mathrm{OH}^{\cdot}
\end{aligned}
$$

Mechanism 1 represents direct oxidation or direct photocatalysis, while mechanism 2 shows indirect oxidation or indirect photocatalysis. In opinion of authors, mechanism 1 is associated with the systems which adsorb pollutants strongly at the photocatalyst surface with firm electronic contact, while mechanism 2 is dominant in systems with weak pollutant adsorption. According to principle, mechanism 2 can be as fast as mechanism 1, or it will be slower, but it is highly improbable to be faster. The electron-hole pair also initiates oxidation and reduction processes of adsorbed substrates. In aqueous solutions, the holes are scavenged by surface hydroxyl groups to generate strong oxidizing hydroxyl radicals $\left(\mathrm{OH}^{*}\right)$, which can promote the oxidation and eventual mineralization of organic compounds [7]. All studies related to photocatalysis show that the presence of molecular oxygen and water is essential during the photo-mineralization process. The trapping of charge carriers by $\mathrm{O}_{2}$ and $\mathrm{H}_{2} \mathrm{O}$ serves to suppress the electron-hole combination, thereby increasing the competitiveness of the light-induced redox processes. Basic principles of photocatalysis as well as the details of rate of degradation and effect of other factors controlling the photo-oxidation have been described in several research papers and review articles [2] [6] [7]. This versatile approach for removal of a broad range of chemical pollutants in waste streams has recently become an area of wide research particularly over the past decade. This paper summarizes recent researches dealing with application of semiconductor photocatalysis for the treatment of water contaminated 
with dyes, pesticides and pharmaceutical components.

\section{Photocatalysis in Dye Removal}

In textile industries, dyeing process generates voluminous quantities of polluted effluents that are discharged on the surface of water bodies and ground water aquifers emerge as responsible for environmental degradation. The effluents consist of high concentrations of dye stuff, biochemical oxygen demand, total dissolved solids, sodium, chloride, sulphate, hardness, heavy metals and carcinogenic dye ingredients [8]. The nature of pollution that accompanies the dyeing industry is primarily due to the non-biodegradable nature of the dyes [9] along with the strong presence of appreciable amounts of toxic trace metals, acids, alkalis and carcinogenic aromatic amines in the effluents [10]. Villegas-Navarro et al., (2001) [11] reported that textile effluents are foxier in terms of LC 50 and exhibit very high toxicity with acute toxicity unit (ATU) levels between 22 and 960. Wynne et al., (2001) [12] noted that textile effluents are highly colored and saline, contain non-biodegradable compounds, and are high in biochemical and chemical oxygen demand (BOD, COD). Reports articulate that the presence of "dye compounds" cause inhibition of microbial activity and some cases may cause failure of biological treatment system. The release of colored wastewaters in the ecosystem is a dramatic source of esthetic pollution, eutrophication, and perturbations in aquatic life. Since the conventional physical (adsorption), biological and chemical methods (chlorination and ozonation) severely lack efficient removal to accomplish the stringent international environmental standard. The technological developments of removal of organic pollutants have become indispensable to the related industries. Various chemical and physical processes like coagulation, electrocoagulation and adsorption on activated carbon are not destructive but only transfer dye from one phase to another [13], moreover, due to the huge occurrence of organics in modern textile dye molecules and stability of dyes, conventional biological treatment methods are ineffective for their decolorization and degradation and these have led to the exploration of other effectual methods like photocatalysis, which can be used to destroy dye compounds using semiconductor photocatalysts under light irradiation [14] and holds several advantages over conventional oxidation processes, such as 1) complete mineralization of the pollutants; 2) use of near-UV or solar light; 3) no addition of other chemicals; and 4) operation at near room temperature [15]. Among the new oxidation methods or "advanced oxidation processes" (AOP), heterogeneous photocatalysis appears as an emerging destructive technology leading to the total mineralization of many organic pollutants [16] as presented in Table 1. A very recent study has reported in details about effect of dyes' nature, concentration level of the various dyes in waste streams, concentration effect and effect of other interfering material on the overall process efficiency of dye photodegradation process [17]. The studies have reported the photocatalytic degradation of poorly soluble indigo dye in aqueous heterogeneous suspension and in the solid state mixed with titanium. Many catalysts like $\mathrm{TiO}_{2}, \mathrm{ZnO}, \mathrm{ZrO}_{2}, \mathrm{WO}_{3}, \mathrm{SrO}_{2}, \mathrm{Fe}_{2} \mathrm{O}_{3}, \mathrm{CeO}_{2}$, CdS and $\mathrm{ZnS}$ had also been made attempted for photocatalytic degradation of a wide variety of environmental contaminants [18] Effect of catalyst on overall performance for dye removal is presented in details by Mehta et al. 2011 [19]. The $\mathrm{TiO}_{2}$ photocatalyst and surface modified $\mathrm{TiO}_{2}$ $\left(\mathrm{Ag}-\mathrm{TiO}_{2}\right)$ has attracted much interest in recent years for its highly active photocatalytic functions, like the ability to decompose of chemical compounds, dye components [20]-[23], as well as super hydrophilic and antibacterial properties [24] [25]. Although photocatalytic degradations of trace toxic organic compounds in water and air have been investigated intensively, there are still few problems for their practical applications [20]. In recent years, vast majority of investigations in the area of photocatalytic degradation of pollutants have employed suspension of the semiconducting particles [15] [21] [26] [27], however, from practical point of view it may not be possible for complete recovery of the photocatalyst used in the reactor. The use of catalyst as slurry, after photocatalytic degradation, leads to the problem of leaching and separation of photocatalyst from the degraded reaction mixture, which necessitates either long time settlement or centrifugation. The need of a difficult, tedious and costly step of filtration to eliminate catalyst particles and recycle the catalyst limits the commercial application of photocatalytic degradation method in practice. To eliminate the filtration step, the concept of immobilizing the photocatalyst on a solid support was developed [28]. Researchers had attempted to study the feasibility of coating the photocatalyst on inert surfaces like glass; polythene fibers and cement surface highlighting the fundamental parameters regarding the preparation of photocatalyst with high photocatalytic activity, the immobilization of powder photocatalyst and the improvement of photocatalyst performance [29]-[32]. Fixation of the catalyst on stationary supports circumvents the need to recover the catalyst from the reaction mixture without any leaching. Many supports were suggested, i.e. quartz, silica, different kinds of glass, ceramics [33], activated 
Table 1. Some commonly used dyes destroyed in photocatalytic degradation.

\begin{tabular}{|c|c|c|}
\hline Name of dyes & Catalyst used & Reference \\
\hline \multirow{6}{*}{ Methylene blue } & $\mathrm{TiO}_{2}$ & [18] \\
\hline & $\mathrm{TiO}_{2}$ & [21] \\
\hline & $\mathrm{TiO}_{2}$ & [27] \\
\hline & $\mathrm{TiO}_{2}$ & {$[32]$} \\
\hline & $\mathrm{TiO}_{2}$ on $\mathrm{HDPE}$ & [40] \\
\hline & $\mathrm{TiO}_{2}$ & [149] \\
\hline \multirow{3}{*}{ Methyl orange } & $\mathrm{TiO}_{2}$ & [21] \\
\hline & $\mathrm{TiO}_{2}$ & [27] \\
\hline & Titania-pillared zirconium phosphate & [48] \\
\hline \multirow{2}{*}{ Indigo } & $\mathrm{TiO}_{2}$ & [16] \\
\hline & $\mathrm{TiO}_{2}$ & [27] \\
\hline \multirow{2}{*}{ Azo dye } & Ag doped $\mathrm{TiO}_{2}$, & [13] \\
\hline & $\mathrm{TiO}_{2}-\mathrm{P} 25$ (Degussa) & [44] \\
\hline \multirow{2}{*}{ Rhodamine B } & $\mathrm{TiO}_{2}$ & [23] \\
\hline & $\mathrm{ZnO}$ & {$[150]$} \\
\hline Methyl violate & $\mathrm{TiO}_{2}$ & [21] \\
\hline Sudan blue II B & $\mathrm{TiO}_{2}$ & [21] \\
\hline \multirow{2}{*}{ Malachite Green } & $\mathrm{TiO}_{2}$ & [20] \\
\hline & $\mathrm{TiO}_{2}$ & {$[150]$} \\
\hline Azodye acid red 18 & $\mathrm{TiO}_{2}$ & [22] \\
\hline Congo red & Anatase nano fiber & [43] \\
\hline
\end{tabular}

carbon [34], zeolites [34] [35], glass fibres [36] [37], stainless steel [36]. By investigating the related expediency and inconveniences [38] it has been reported that commercial glass fibres covered with $\mathrm{TiO}_{2}$ and suspended $\mathrm{TiO}_{2}$ have comparable activities for the transformation of phenol. Commercial inorganic fibres coated with $\mathrm{TiO}_{2}$ were reported to be less efficient than suspended $\mathrm{TiO}_{2}$, but much more efficient than $\mathrm{TiO}_{2}$ deposited by sol-gel dip coating on red brick, cement or glass [37]. It was also reported that porous supports such as pumice stone can be impregnated with $\mathrm{TiO}_{2}$ and used as immobilized photocatalyst for the transformation of nitrobenzenesulfonic acids, in thin-film fixed bed reactor to prevent damage in the support by stirring [39]. Efficient degradation of methylene blue dye was also achieved with multilayer coating of $\mathrm{TiO}_{2}$ on HDPE [40]. Further efforts were made to improvise the photocatalytic technique by using a variety of reactor designs and arrangements. Several authors had reported the efficient applications of photocatalytic reactor assisted with UV irradiation to mineralize dyes [41]-[44]. Modifications of $\mathrm{TiO}_{2}$ catalyst has become an inquisitive area of photocatalytic degradation research. Doping of $\mathrm{TiO}_{2}$ with carbon was found to be interesting to enhance the performance of photocatalyst [45]. Similar attempts have also reported with erbium [46], tungsten [47] zirconium phosphate [48] and various ions [49]. All recent reviews and publications supports the potency of photocatalytic degradation technique with immense advantages over conventional of dye treatment methods but require more investigation on the extent of degradation and nature of the dye degraded products which in turn may raise further issues regarding practical applications. In context of dye removal, though there exists several technical advantages of photocatalysis process over other conventional techniques but, being an emerging technology detail of the economic aspects of dye degradation is scanty. Since this process can also use sunlight as energy resource other than synthetic energy 
sources so, it is expected that the process will be cost effective in terms of energy requirement [5].

\section{Application of Photocatalysis in Treating Pesticide Contaminated Waste Stream}

Although the usage of these pesticides has been prohibited since 20 years, the original compounds as well as their degradation products have still been found in some foods and surface water [50]. Increasing pesticide applications and improper wastewater disposal methods are of particular concern for the freshwater (surface and groundwater), coastal and marine environments [51]. Low-level residues of pesticides in water generally do not acquire acute toxicity problems, but chronic effects are likely to be of concern [52]. This is because pesticides can harm with chronic effects such as cancer [53], Parkinson's disease [54], reproductive effects, fetal damage, delayed neurologic manifestations and possible immunologic disorders [55]. Pesticides represent a class of highly toxic anthropogenic compounds, which have led to search for a powerful method of degradation due to their persistence and bio-accumulative abilities [56]. These have motivated immense researches to develop efficient and rapid methods of degrading pesticides including microbial degradation, mechanochemical destruction, thermal degradation and photocatalytic degradation. In microbial degradation [57], only special kinds of microorganisms are used to degrade targeted pesticide. Though the action is very specific, but the cultivation and purification of the microorganism as well as the degradation are reported as time consuming and laborious. Some pesticides being bio-recalcitrant, non-biodegradable, the biological process does not define to be an ideal process and other more efficient technologies such as advanced oxidation technologies (AOTs) have been proposed for treatment of pesticides-polluted water [58]-[60] which allow pesticides to be removed by mineralization. The photo-mineralization of organic compounds by semiconductor photocatalysts such as $\mathrm{TiO}_{2}$ or $\mathrm{ZnO}$ has become an area of intensive research, as ideally the end products of these processes are carbon dioxide, water and inorganic mineral salts [61], which have minimum environmental impact as presented in Table 2. In area of basic and applied researches reviewed, photocatalytic process with anatase $\mathrm{TiO}_{2}$ is competent, since it operates in ambient temperature and pressure with low energy photons $(\lambda<388 \mathrm{~nm})$, requires no chemical reagents except oxygen in the ambient air [61]. Titanium dioxide appears as the most widely accepted photocatalyst for pesticide destruction in water as it is considered as very efficient catalyst that, unlike other semiconductors, being non toxic, stable to photo-corrosion, low cost and workable in sunlight considered as energy source [61]. Ahmed et al., 2011 [4] presented a complete review on process parameters of heterogeneous photocatalysis that affects the performance of photocatalytic degradation. They studied some important aspects like composition of catalyst, light intensity and wave length, nature of pollutants, catalyst loading, $\mathrm{pH}$ of medium, mode of catalyst

\begin{tabular}{|c|c|c|}
\hline Name of pesticides & Catalyst used & Reference \\
\hline S-triazines herbicides & $\mathrm{TiO}_{2}$ & [151] \\
\hline carboxin, oxycarboxin fungicides & $\mathrm{TiO}_{2}$ & [7] \\
\hline \multirow{2}{*}{ carbamate insecticides (carbaryl) } & $\mathrm{TiO}_{2}$ & [152] \\
\hline & $\mathrm{TiO}_{2}$ & [153] \\
\hline Scala ${ }^{\circledR}$ & Solar photo-fenton & [68] \\
\hline phosphamidon & $\mathrm{TiO}_{2}$ and $\mathrm{ZnO}$ & [154] \\
\hline Bromophos methyl & Aqueous $\mathrm{TiO}_{2}$ suspension & [62] \\
\hline chlorophenol pesticides & Aqueous $\mathrm{TiO}_{2}$ suspension & [61] \\
\hline chlortoluron & Coated $\mathrm{TiO}_{2}$ & [63] \\
\hline cyproconazole & Coated $\mathrm{TiO}_{2}$ & [63] \\
\hline fenitrothion & $\mathrm{TiO}_{2}$ & [7] \\
\hline DDT & Aqueous $\mathrm{TiO}_{2}$ dispersion & [155] \\
\hline
\end{tabular}


application (suspended vs. immobilized system), influence of catalyst doping on the overall degradation process. Another review of Devipriya and Yesodharan, (2005) [7] reports the detail mechanism of photodegradation process and several case studies on different group of insecticides like, OP insecticides, organochlorine insecticides, carbamate insecticides, numerous herbicides (bentazone, carbetamide, monuron, S-triazines) and several fungicides (Pyrimethanil, chlorothalonil, diclofuanid, carboxin, oxycarboxin) using $\mathrm{TiO}_{2}$ and $\mathrm{ZnO}$. The photocatalytic degradation of S-triazines herbicides (atrazine, simazine, trietazine, prometon and prometryn) was first studied by Pelizzetti et al., (1990) [62]. Several other publications about the solar $\mathrm{TiO}_{2}$ photocatalyzed oxidation of S-triazines also revealed the full disappearance of the herbicide with incomplete mineralization and several degraded products. Anilide and amide herbicides also exhibited similar behavior under catalytic degradation. Enormous studies were also made on organophosphorous insecticides and organochlorine insecticides and chlorophenol pesticides [61]. Though photocatalytic degradation is a promising route of targeted pesticide mineralization, but may be affected by interfering compounds of real waste stream. Reports state that for a particular pesticide the degradation kinetic may differ from laboratory formulation in actual agricultural waste. Studies have also conducted commercial pesticide solutions of chlortoluron and cyproconazole highlighting the effects of interfering compounds and additives; exemplify the significantly lower degradation rate compared to simulated solution [63] [64]. Photocatalytic study also focuses on development of various reactor systems for mineralization of pesticides, like fixed bed fluidized bed, immobilized membrane fixed on reactor wall, reactive wall reactor, immobilized film coating a bundle of optical fibers. Some novel type of reactors like "rotating disk photocatalytic reactor" to mineralize lindane and chlorophenols in continuous flow mode [65] and photocatalyst coated "rotating drum reactor" to degrade phenol has been reported [66]. A study, featuring details of various reactor configurations by coupling photocatalysis with membrane process has been reported to mineralize a simulated solution of 4-nitrophenol with conclusively establishing the advantages of hybrid system over conventional reactor systems [67]. Coupling of photocatalysis with biological treatment [68] and wetland reactors [69] also proved effective to treat the real industrial waste water streams. Zinc oxide also exhibits interesting results which may be due to the wide band gap, large excitation binding energy, and piezoelectric properties. UV light with wavelength shorter than $380 \mathrm{~nm}$ was reported to excite the electrons in valence band to conduction band [70] for $\mathrm{ZnO}$. They have reported the effective use of $\mathrm{ZnO}$ as photosensitizer in presence of an oxidant to treat several commonly used pesticides in pilot plant scale in presence of sunlight [4]. Several publications are available which substantiate the efficiency of $\mathrm{TiO}_{2}$ as a photocatalyst for detoxification of pesticide contaminated water [63] [71] [72]. Recently, $\mathrm{TiO}_{2}$ film has been developed and applied to degrade polychlorinated debenzop-dioxine under UV irradiation [73]. Moreover, low-density polyethylene- $\mathrm{TiO}_{2}$ nanocomposite film has usually been selected to degrade polyethylene [74]. Yu et al. (2007) [75] have reported the photocatalytic degradation of organochlorine pesticides on a nano- $\mathrm{TiO}_{2}$ coated film. Quite a few authors have reviews on the photo catalytic transformation of pesticides highlighting the complete degradation path way [62] [76]. However, several major drawbacks are also associated like, lack of an efficient visible light harvesting catalyst [77], the design of photoreactor [78], the recovery and reuse of titanium dioxide [77], the generation of toxic intermediates [62] [79] as well as concern in regard to catalyst deactivation [80]. Since, in photocatalytic detoxification technique, complete mineralization is hard to attain so, it obviates further toxicological analysis of end products. Since the heterogeneous photocatalytic treatment involve complex reaction mechanisms so, information regarding the chemistry of various classes of pollutants under reaction condition appears mandatory to know, as well as identification of harmful intermediates, which can be toxic, and in some cases, more persistent than the original substrate. Further, byproduct evaluation is brought into view, considering as a crucial factor in photocatalytic degradation of pesticides to assess overall process efficiency and feasibility. Among several rapid and established methods for direct acute toxicity assessment (DTA) [81], Microtox ${ }^{\mathrm{TM}}$ was reported as especially rapid and reliable [82]. Taking into account the amount of reported work and the potential practical applications dealing with photocatalysis of pesticide residues, economic aspects are continuously analyzed by several research groups [83]-[85] regarding the composition of the solution, the absorption of light and the reactor design.

\section{Photocatalysis in Treating EDCs in Pharmaceutical Waste Water}

EDCs are a special group of chemicals having steroid-like structures, that can disturb normal endocrine functions directly or indirectly through interaction with receptor-mediated processes such as steroid hormone receptors even at very low concentration $\left(\mu \mathrm{gL}^{-1}\right.$ and $\mathrm{ng} \mathrm{L}^{-1}$ range) [86] [87]. Studies had revealed that their propensi- 
ty is to mimic endogenous hormones and to inhibit normal hormone activities and metabolism [88]. Reports substantiate, they can also influence thyroid hormone secretion patterns, [86] [88], abnormal sexual development in animals [88] [89] and a decrease in the average numbers of human spermatozoa [87] [90]. Studies have reported the development of "product resistant microbes" in aquatic environment [91] [92]; retardation of nitrite oxidation [93]; methanogenesis [93] [94] and increased toxicity of chemical metabolites [95]. As cited in experimental review literatures, EDCs in wastewater and the environment comprising antibiotics (e.g., sulfamethoxazole, erythromycin, and roxithromycin); analgesic drugs such as codeine and anti-epileptic drugs inclusive of carbamazepine; and non-prescription drugs such as acetaminophen and ibuprofen [91] [96]-[98]. Other class of important EDCs from industries include "bisphenol A", which leaches from food cans, polycarbonate water jugs, and dental composites; "dioxin", which is a near-ubiquitous byproduct of combustion from incinerators, paper bleaching and foundries; "nonylphenols", which are added to polyvinylchloride (PVC) plastic and are also a byproduct of industrial detergents and pesticide decomposition; "polychlorinated biphenyls" (PCB) associated with adhesives and electrical transformers; and "vinclozolin", a common fungicide [99]. EDCs also include natural and synthetic hormones such as human and animal steroids (estradiol, estrone, and estriol) and contraceptives (e.g., ethynylestradiol). Although the adverse effects of EDCs on people and aquatic ecosystems are not clearly understood but, it is becoming increasingly important to adapt the existing wastewater treatment processes to improvise their potential in removing micro-pollutants like EDCs. To ensure compliance with future discharge requirements, upgrading the existing wastewater-treatment facilities and implementation of new technologies is envisaged as the next step in improvement of wastewater treatment. A number of advanced treatment techniques are available and these include membrane filtration technologies [100] [101], advanced oxidation processes (AOPs) [102], ultraviolet (UV) irradiation, and hybrid systems [103]. Membrane technology has become a technically and economically feasible alternative for water and wastewater treatment, especially because of compact reactor volumes and is not limited by the settling characteristics of sludge [104]-[106]. In membrane filtration process, the release of pollutants retained by the membrane, however, does not eliminate the risk to the environment [100] [101] [107]. Many reported that the heterogeneous photocatalysis in the presence of semiconductor metal oxides act as a fast-growing field of basic and applied research and a promising tool for water treatment with effective degradation of major pharmaceuticals and EDCs without formation of harmful intermediates [105] [108] [109] as presented in Table 3. The photocatalyst $\mathrm{TiO}_{2}$ based treatment system could also be integrated as a pre- or post-biological wastewater treatment to enhance the biotransformation process for pharmaceutical compounds [110] [111] with advantages of low chemical input, high energy efficiency and the capacity to use renewable and pollution-free solar energy [112]. Immense studies have been conducted on the photocatalytic degradation of antibiotics by several authors [114] [115], which is having undesirable effects on living organisms. They cause an increasing resistance of bacteria to drugs, spreading of antibiotic resistance genes in the environment and having genotoxic effects on microorganisms [91] [115] [116]. Numerous researchers had focused on photocatalytic degradation of very common drug components focusing on their concentration in aqueous stream, effect of drug component nature, their concentration effect different approaches of increasing the process efficiency, photo reaction design and economic aspects [117]. Some articles have reported the ability of heterogeneous photocatalysis to improve tetracycline biodegradability [118] [119] and on the identification of tetracycline by-products formed during the photocatalytic treatment [114]. It has been shown from various studies the availability of photo degradation of norfloxacine in presence of algae and Fe (III) in presence of mercury lamp [120]. The authors have mentioned a novel approach of using algae for degradation of antibiotics and also the combined effect of photodegradation and algal concentration on the degradation behavior of the antibiotics. Their studies claim the credit of being an informative study for understanding the photochemical degradation of antibiotics in aqueous environment. A review highlighting the presence of organic contaminants specially the pharmaceutical and personal care products have been reported by Ratola et al., (2012) [121]. This review also focuses on the recent trends of water treatment process, fate and elimination of five different classes of chemicals namely, pharmaceutical and personal care products, illicit drugs, prohibited doping substances, persistent organic pollutants and perfluorinated compounds. Photocatalytic degradation of diclofenac by $\mathrm{TiO}_{2}$ photocatalysis and bioassay of toxicity has been reported by Rizzo et al., (2009b) [122]. In their study the degradation kinetics and mineralization of diclofenac (DCF) by $\mathrm{TiO}_{2}$ photocatalysis were investigated in terms of UV absorbance and COD measurements in a batch reactor system. A set of bioassays was performed to evaluate the potential detoxification of DCF on Daphnia magna, Pseudokirchneriella subcapitata and Artemia salina was observed that fresh water unicellular algae ( $P$. subcapitata) is highly sensitive to the degraded 
Table 3. Some EDCs mineralized in photocatalytic degradation.

\begin{tabular}{ccc}
\hline Name of EDCs & Catalyst used & Reference \\
\hline Tetracycline & $\mathrm{TiO}_{2}$ & {$[118]$} \\
& $\mathrm{TiO}_{2}$ & {$[119]$} \\
& $\mathrm{TiO}_{2}$ & {$[156]$} \\
Tylosin & $\mathrm{TiO}_{2}$ & {$[114]$} \\
Oxolinic acid & $\mathrm{TiO}_{2}$ & {$[157]$} \\
Levonorgestrel & $\mathrm{TiO}_{2} \mathrm{Suspension}$ & {$[113]$} \\
Estrogenic steroid hormones & $\mathrm{TiO}_{2}$ & {$[124]$} \\
& $\mathrm{TiO}_{2}$ & {$[137]$} \\
& $\mathrm{TiO}_{2}$ & {$[138]$} \\
Bisphenol A & $\mathrm{TiO}_{2}$ & {$[139]$} \\
& $\mathrm{Bi}_{2} \mathrm{WO}_{6}$ & {$[140]$} \\
& $\mathrm{Bi}_{2} \mathrm{WO}_{6}$ & {$[141]$} \\
Atrazine & $\mathrm{TiO}_{2}$ & {$[122]$} \\
Diclofhynylestradiol & $\mathrm{TiO}_{2}$ & {$[123]$} \\
Carbamazepine & $\mathrm{MBR}$ & $\mathrm{TiO}_{2}$ \\
\hline
\end{tabular}

product and not ecofriendly effluent. The toxicity was also reported to increase with increasing catalyst loading and DCF concentration. Photocatalytic treatment was found to be effective in treating highly concentrated carbamazepine from synthetic hospital waste water [123]. Authors used a titanium dioxide $\left(\mathrm{TiO}_{2}\right)$ nanofiber based wastewater treatment process as a pre-treatment system to treat and enhance the biodegradability of carbamazepine (CBZ), in synthetic hospital wastewater and concluded that the $\mathrm{TiO}_{2}$ pre-treatment system was capable of removing about $78 \%$ of CBZ from the influent wastewater within a $4 \mathrm{~h}$ reaction time. Steroid hormones, an important class of EDCs having strong potential to disrupt endocrine and other vital systems in aquatic organisms also reported to response strongly to photocatalytic degradation [124]. The heterogeneous photocatalysis process using $\mathrm{TiO}_{2}$ was applied successfully for the removal of estrogens by several authors [125]-[136]. A recent review emphasizes on removal processes of estrogenic hormone (estrone [E1], 17b-estradiol [E2], estriol [E3], synthetic 17a-ethinylestradiol [EE2]) has covered a broad range of possible elimination routes like, adsorption, membrane filtration, biological processes (bacteria, microalgae, enzyme), advanced oxidation processes (photolysis, heterogeneous photocatalysis) [137] and finally confers the concept of AOPs being more advantageous for their high removal efficiency compare to other processes and are thought to be one of the most promising treatments to deal with the problem of estrogens removal from contaminated water. Though $\mathrm{TiO}_{2}$ has been widely used in degradation of organic chemicals in water and could completely mineralize bisphenol $\mathrm{A}$ to $\mathrm{CO}_{2}$ under UV irradiation [138] [139] recent publication by Wang et al. (2012) [140] reports the efficiency of $\mathrm{Bi}_{2} \mathrm{WO}_{6}$ in photodegradation of "bisphenol A" in aqueous medium. Their studies provide useful information about an alternative potential photocatalyst in treating organic pollutants in water in real application [141]. From existing literatures, though it is clear that photocatalytic degradation can efficiently be used in treating EDCs contaminated waste water from pharmaceutical industries but, most of them are related to the study of the effectiveness and the photocatalytic mechanism of targeted components. It is now appears to be crucial to maintain the quality of the final processed discharge ecofriendly for which ongoing researches should be oriented for more detail investigation on the degraded product identification and toxicity analysis. 


\section{Future Prospects of Membrane Separation and Photocatalysis in Waste Water Treatment}

In sphere of advanced wastewater treatment technologies, integration of the membrane separation process with photocatalysis offers a novel research topic. Modification of the membrane with photocatalyst improves the operational performance in terms of good antifouling properties [142]-[145]. In waste water treatment, increase in the time between membranes cleaned or by reducing the cost for cleansing of lead to significant improvements of process. Integration membrane bioreactor (MBRs) with photocatalytic oxidation, offers great operational flexibility and superior performances in removing suspended solids and micropollutants [123] [141] [146]. The absence of suspended solids in the MBR effluent executes particular benefit for application of UV light, avoiding light shielding and scattering by suspended particles. Moreover, the use of MBR instead of conventional activated sludge systems offers further advantage of higher potential for biomass acclimation and augmentation, especially when operated at high sludge retention time [123]. Coupling of MBR with photocatalysis can also be a novel approach of treating wastewater from dye and agricultural land for mineralization of the respective pollutants and recycling of treated effluent for non potable end uses. Researches in this field are sparse and need thorough studies to make this approach profitable in practice. This review aims to make researchers more attentive in the novel approaches of waste water treatment to control pollution, protection of environmental and to obtain zero discharge effluent. Types of membrane those are normally modified with catalyst, modification techniques and about the catalyst life cycle are presented in details by several research groups [147] [148].

\section{Conclusion}

This review aims to focus on the recent application and advances for the heterogeneous photocatalytic system to reveal its efficacy of wastewater treatment specifically dye/textile effluent, pesticide contaminated water and pharmaceutical effluents. In most of the reviewed literature, $\mathrm{TiO}_{2}$ has been suggested to be an efficient and profitable photocatalyst for mineralization of organic pollutants such as dyes, pesticides and EDCs in wastewater in the presence of UV, visible or solar light but some researchers have also aimed to explore novel low cost catalysts composition. Majority of studies are related to optimization of degradation process parameters, studies on kinetics and mechanistic path way of degradation which are crucial for efficient design and the application of the photocatalytic degradation process to ensure sustainable operation. In spite of extensive process investigations, understanding of photoreactor design and its modeling as well as the scale up policy seems inadequate which limits the industrial exploitation of the photocatalytic degradation technique. The application of this technique for real waste waters require further investigation to achieve eco-friendly discharge. This review is not comprehensive but covers the recent application and developments of photocatalysis in treatment of industrial waste water and is hoped to be informative to relate researchers for betterment of the existing processes.

\section{References}

[1] WHO (2004) http://www.who.int/water_sanitation_health/factsfigures2005.pdf

[2] Malato, S., Fernandez-Ibanez, P., Maldonado, M.I., Blanco, J. and Gernjak, W. (2009) Decontamination and Disinfection of Water by Solar Photocatalysis: Recent Overview and Trends. Catalysis Today, 147, 1-59. http://dx.doi.org/10.1016/j.cattod.2009.06.018

[3] Matsunaga, T., Tomoda, R., Nakajima, T. and Wake, H. (1985) Photoelectrochemical Sterilization of Microbial Cells by Semiconductor Powders. FEMS Microbiology Letters, 29, 211-214. http://dx.doi.org/10.1111/j.1574-6968.1985.tb00864.x

[4] Ahmed, S., Rasul, M.G., Brown, R. and Hashib, M.A. (2011) Influence of Parameters on the Heterogeneous Photocatalytic Degradation of Pesticides and Phenolic Contaminants in Wastewater: A Short Review. Journal of Environmental Management, 92, 311-330. http://dx.doi.org/10.1016/j.jenvman.2010.08.028

[5] Ibhadon, A.O. and Fitzpatrick, P. (2013) Heterogeneous Photocatalysis: Recent Advances and Applications. Catalysts, 3, 1-29. http://dx.doi.org/10.3390/catal3010189

[6] Robertson, P.K.J., Robertson, J.M.C. and Bahnemann, D.W. (2012) Removal of Microorganisms and Their Chemical Metabolites from Water Using Semiconductor Photocatalysis. Journal of Hazardous Material, 211, 161-171. http://dx.doi.org/10.1016/j.jhazmat.2011.11.058

[7] Devipriya, S. and Yesodharan, S. (2005) Photocatalytic Degradation of Pesticide Contaminants in Water. Solar Energy Material and Solar Cell, 86, 309-348. http://dx.doi.org/10.1016/j.solmat.2004.07.013 
[8] Tchobanoglous, G. and Burton, F.L. (1995) Wastewater Engineering: Treatment, Disposal and Reuse. Tata McGrawHill Publishing Co. Ltd, New Delhi.

[9] Dave, R.S. and Patel, A.R. (2010) Photochemical and Photocatalytic of Cypermethrin under UV Radiation. Der pharma Chemical, 2, 152-158.

[10] Manivasakam, N. (2003) Industrial Effluents Origin, Characteristics, Effects, Analysis and Treatment. Sakthi Publications, Coimbatore.

[11] Villegas-Navarro, A., Ramirez, M.Y., Salvador-S, M.S. and Gallardo, J.M. (2001) Determination of Wastewater LC 50 of the Different Process Stages of the Textile Industry. Ecotoxicology and Environmental Safety, 48, 56-61. http://dx.doi.org/10.1006/eesa.2000.1986

[12] Wynne, G., Maharaj, D. and Buckley, C. (2001) Cleaner Production in the Textile Industry—Lessons from the Danish Experience. School of Chemical Engineering, University of Natal, Durban, 3-17.

[13] Mirkhani, V., Tangestaninejad, S., Moghadam, M., Hibibi, M.H. and Vartoony, R. (2009) Photocatalytic Degradation of Azo Dyes Catalyzed by Ag Doped $\mathrm{TiO}_{2}$ Photocatalyst. Journal of the Iranian Chemical Society, 6, 578-587.

[14] Neppolian, B., Choi, H.C., Sakthivel, S., Arabindoo, B. and Murugesun, V. (2002) Solar/UV-Induced Photocatalytic Degradation of Three Commercial Textile Dyes. Journal of Hazardous Materials, 89, 303-317. http://dx.doi.org/10.1016/S0304-3894(01)00329-6

[15] Srivastava, V.S. (2012) Photocatalytic Degradation of Methylene Blue Dye and Chromium Metal from Wastewater Using Nanocrystalline $\mathrm{TiO}_{2}$ Semiconductor. Archives of Applied Science Research, 4, 1244-1254.

[16] Vautier, M., Guillard, C. and Herrmann, J.M. (2001) Photocatalytic Degradation of Dyes in Water: Case Study of Indigo and of Indigo Carmine. Journal of Catalysis, 201, 46-59. http://dx.doi.org/10.1006/jcat.2001.3232

[17] Julkapli, N., Bagheri, S. and Hamid, S.B.A. (2014) Recent Advances in Heterogeneous Photocatalytic Decolorization of Synthetic Dyes. The Scientific World Journal, 2014, Article ID: 692307.

[18] Talebian, N. and Nilforoushan, M.R. (2010) Comparative Study of the Structural Optical and Photocatalytic Properties of Semiconductor Metal Oxides toward Degradation of Methylene Blue. Thin Solid Films, 518, 2210-2215. http://dx.doi.org/10.1016/j.tsf.2009.07.135

[19] Mehta, P., Mehta, R., Surana, M. and Kabra, B.V. (2011) Influence of Operational Parameters on Degradation of Commercial Textile Azo Dye Acid Blue 113 (Cyanine 5R) by Advanced Oxidation Technology. Journal of Current Chemical and Pharmaceutical Science, 1, 28-36.

[20] Tayade, R.J., Surolia, P.K., Kulkarni, R.G. and Jasra, R.V. (2007) Photocatalytic Degradation of Dyes and Organic Contaminants in Water Using Nanocrystalline Anatase and Rutile $\mathrm{TiO}_{2}$. Science and Technology of Advanced Materials, 8, 455-462. http://dx.doi.org/10.1016/j.stam.2007.05.006

[21] Hosseinnia, A., Keyanpour, R.M. and Pazouki, M. (2010) Photo-Catalytic Degradation of Organic Dyes with Different Chromophores by Synthesized Nanosize $\mathrm{TiO}_{2}$ Particles. World Applied Science Journal, 8, 1327-1332.

[22] Mozia, S., Tomaszewska, M. and Moraoski, A.W. (2005) Photocatalytic Degradation of Azo-Dye Acid Red 18. Desalination, 185, 449-456. http://dx.doi.org/10.1016/j.desal.2005.04.050

[23] Yang, J., Chen, C., Ji, H., Ma, W. and Zhao, J. (2005) Mechanism of TiO ${ }_{2}$-Assisted Photocatalytic Degradation of Dyes under Visible Irradiation: Photoelectrocatalytic Study by $\mathrm{TiO}_{2}$-Film Electrodes. The Journal of Physical Chemistry B, 109, 21900-21907. http://dx.doi.org/10.1021/jp0540914

[24] Sobczynski, A., Duczmal, L. and Zmudzinski, W. (2004) Phenol Destruction by Photocatalysis on $\mathrm{TiO}_{2}$ : An Attempt to Solve the Reaction Mechanism. Journal of Molecular Catalysis A: Chemistry, 213, 225-230. http://dx.doi.org/10.1016/j.molcata.2003.12.006

[25] Al-Qaradawi, S. and Salman, S.R. (2002) Photocatalytic Degradation of Methyl Orange as a Model Compound. Journal of Photochemistry and Photobiology A, 148, 161-168. http://dx.doi.org/10.1016/S1010-6030(02)00086-2

[26] Joshi, K.M. and Shrivastava, V.S. (2011) Degradation of Alizarine Red-S (a Textiles Dye) by Photocatalysis Using Zno and $\mathrm{TiO}_{2}$ as Photocatalyst. International Journal of Environmental Science, 2, 8-21.

[27] Lin, W.C., Yang, W.D. and Jheng, S.Y. (2012) Photocatalytic Degradation of Dyes in Water Using Porous Nanocrystalline Titanium Dioxide. Journal of the Taiwan Institute of Chemical Engineers, 43, 269-274. http://dx.doi.org/10.1016/j.jtice.2011.10.010

[28] Venkata Subba Rao, K., Rachel, A., Subrahmanyam, M. and Boul, P. (2003) Immobilization of $\mathrm{TiO}_{2}$ on Pumice Stone for the Photocatalytic Degradation of Dyes and Dye Industry Pollutants. Applied Catalysis B: Environmental, 46, 77-85. http://dx.doi.org/10.1016/S0926-3373(03)00199-1

[29] Wang, J.A., Limas-Ballesteros, R., Lopez, T., Moreno, R., Gómez, R., Novaro, O. and Bokhimi, X. (2001) Quantitative Determination of Titanium Lattice Defects and Solid State Reaction Mechanism in Iron Doped $\mathrm{TiO}_{2} \mathrm{Photocataly-}^{-}$ sis. The Journal of Physical Chemistry B, 105, 9692-9698. http://dx.doi.org/10.1021/jp0044429 
[30] Yu, J.C., Yu, J.G. and Zhao, J.C. (2002) Enhanced Photocatalytic Activity of Mesoporous and Ordinary TiO ${ }_{2}$ Thin Films by Sulfutic Acid Treatment. Applied Catalysis B: Environmental, 36, 31-43. http://dx.doi.org/10.1016/S0926-3373(01)00277-6

[31] Yu, J., Yu, J.C., Ho, W.K. and Jiang, Z. (2002) Effect of Calcinations Temperature on the Photocatalytic Activity and Photo Induced Super-Hydrophilicity of Mesoporous $\mathrm{TiO}_{2}$ Thin Films. New Journal of Chemistry, 26, 607-613. http://dx.doi.org/10.1039/b200964a

[32] Nguyen-Phan, T.D. and Shin, E.W. (2011) Morphological Effect of $\mathrm{TiO}_{2}$ Catalysts on Photocatalytic Degradation of Methylene Blue. Journal of Industrial and Engineering Chemistry, 17, 397-400. http://dx.doi.org/10.1016/j.jiec.2011.05.013

[33] Fujishima, A., Hashimoto, K. and Watanabe, T. (1999) $\mathrm{TiO}_{2}$ Photocatalysis Fundamentals and Applications. BKC Inc., Tokyo.

[34] Torimoto, T., Ito, S., Kuwabata, S. and Yoneyama, H. (1996) Effects of Adsorbents Used as Supports for Titanium Dioxide Loading on Photocatalytic Degradation of Propyzamide. Environmental Science and Technology, 30, 12751281. http://dx.doi.org/10.1021/es950483k

[35] Fox, M.A., Doan, K.E. and Dulay, M.T. (1994) the Effect of the "Inert” Support on Relative Photocatalytic Activity in the Oxidative Decomposition of Alcohols on Irradiated Titanium Dioxide Composites. Research on Chemical Intermediates, 20, 711-722. http://dx.doi.org/10.1163/156856794X00504

[36] Rachel, A., Subrahmanyam, M. and Boule, P. (2002) Comparison of Photocatalytic Efficiencies of TiO2 in Suspension and Immobilised Form for the Photocataytic Degradation of Nitrobenzene Sulfonic Acid. Applied Catalysis B: Environmental, 37, 301-308. http://dx.doi.org/10.1016/S0926-3373(02)00007-3

[37] Fernández, A., Lassaletta, G., Jiménez, V.M., Justo, A., González-Elipe, A.R., Herrmann, J.M., Tahiri, H. and Ait-Ichou, Y. (1995) Preparation and Characterization of $\mathrm{TiO}_{2}$ Photocatalysts Supported on Various Rigid Supports (Glass, Quartz and Stainless Steel). Comparative Studies of Photocatalytic Activity in Water Purification. Applied Catalysis B: Environmental, 7, 49-63. http://dx.doi.org/10.1016/0926-3373(95)00026-7

[38] Mikula, M., Brezová, V., Ceppan, M., Pach, M. and Karpinskeý, Ĺ. (1995) Comparison of Photocatalytic Activity of Sol-Gel $\mathrm{TiO}_{2}$ and P25 $\mathrm{TiO}_{2}$ Particles Supported on Commercial Fiberglass Fabric. Journal of Materials Science Letters, 14, 615-616. http://dx.doi.org/10.1007/BF00586156

[39] Rachel, A., Lavédrine, B., Subrahmanyam, M. and Boule, P. (2002) Use of Porous Lavas as Supports of Photocatalysts. Catalysis Communications, 3, 165-171. http://dx.doi.org/10.1016/S1566-7367(02)00076-6

[40] Kasanen, J., Salstela, J. and Suvanto, M. (2011) Photocatalytic Degradation of Methylene Blue in Water Solution by Multilayer $\mathrm{TiO}_{2}$ Coating on HDPE. Applied Surface Science, 258, 1738-1743. http://dx.doi.org/10.1016/j.apsusc.2011.10.028

[41] Karkmaz, M., Puzenat, E., Guillard, C. and Herrmann, J.M. (2004) Photocatalytic Degradation of the Alimentary Azo Dye Amaranth Mineralization of the Azo Group to Nitrogen. Applied Catalysis B: Environmental, 51, 183-194. http://dx.doi.org/10.1016/j.apcatb.2004.02.009

[42] Tayade, R.J., Natarajan, T.S. and Bajaj, H.C. (2009) Photocatalytic Degradation of Methylene Blue Dye Using Ultraviolet Light Emitting Diodes. Industrial \& Engineering Chemistry Research, 48, 10262-10267. http://dx.doi.org/10.1021/ie9012437

[43] Chong, M.N., Jin, B. and Zhu, H.Y. (2009) Application of H-Titanate Nanofibers for Degradation of Congo Red in an Annular Slurry Photoreactor. Chemical Engineering Journal, 150, 49-54. http://dx.doi.org/10.1016/j.cej.2008.12.002

[44] Zayani, G., Bousselmi, L., Mhenni, F. and Ghrabi, A. (2009) Solar Photocatalytic Degradation of Commercial Textile Azo Dyes: Performance of Pilot Plant Scale Thin Film Fixed-Bed Reactor. Desalination, 246, 344-352.

[45] Tseng, Y.H. and Kuo, C.H. (2011) Photocatalytic Degradation of Dye and $\mathrm{No}_{\mathrm{x}}$ Using Visible-Light-Responsive Carbon Containing $\mathrm{TiO}_{2}$. Catalysis Today, 174, 114-120. http://dx.doi.org/10.1016/j.cattod.2011.02.011

[46] Lee, D.Y., Lee, M.H. and Cho, N.I. (2012) Preparation and Photocatalytic Degradation of Erbium Doped Titanium Dioxide Nanorods. Current Applied Physics, 12, 1229-1233. http://dx.doi.org/10.1016/j.cap.2012.03.007

[47] Saepurahman, Abdullah, M.A. and Chong, F.K. (2010) Preparation and Characterization of Tungsten-Loaded Titanium Dioxide Photocatalyst for Enhanced Dye Degradable. Journal of Hazardous Materials, 176, 451-458. http://dx.doi.org/10.1016/j.jhazmat.2009.11.050

[48] Chen, R., Wang, J., Wang, H., Yao, W. and Zhong, J. (2011) Photocatalytic Degradation of Methyl Orange in Aqueous Solution over Titania-Pillarred $\alpha$-Zirconium Phosphate. Solid State Sciences, 13, 630-635 http://dx.doi.org/10.1016/j.solidstatesciences.2010.12.037

[49] Choi, J., Park, H. and Hoffmann, M.R. (2010) Effects of Single Metal-Ion Doping on the Visible-Light Photoreactivity of $\mathrm{TiO}_{2}$. The Journal of Physical Chemistry C, 114,783-792. http://dx.doi.org/10.1021/jp908088x 
[50] Binbin, Y.U., Bin, Z.J., Fen, G.L., Qing, Y.X., Mei, Z.L. and Xi, C. (2008) Photocatalytic Degradation Investigation of Dicofol. Chinese Science Bulletin, 53, 27-32.

[51] Abdennouri, M., Baâlala, M., Galadi, A., Makhfouk, M., El Bensitel, M., Nohair, K., Sadiq, M., Boussaoud, A. and Barka, N. (2011) Photocatalytic Degradation of Pesticides by Titanium Dioxide and Titanium Pillared Purified Clays. Arabian Journal of Chemistry. http://dx.doi.org/10.1016/j.arabjc.2011.04.005

[52] Smith, C.N., Carsel, R.F. and Parrish, R.S. (1987) Estimating Sample Requirements for Field Evaluations of Pesticide Leaching. Environmental Toxicology and Chemistry, 6, 343-357. http://dx.doi.org/10.1002/etc.5620060504

[53] Younes, M. and Galal-Gorchev, H. (2000) Pesticides in Drinking Water-A Case Study. Food and Chemical Toxicology, 38, S87-S90. http://dx.doi.org/10.1016/S0278-6915(99)00132-5

[54] Tanner, C.M., Kamel, F., Webster Ross, G., Hoppin, J.A., Goldman, S.M., Korell, M., Marras, C., Bhudhikanok, G.S., Kasten, M., Chade, A.R., Comyns, K., Richards, M.B., Meng, C., Priestley, B., Fernandez, H.H., Cambi, F., Umbach, D.M., Blair, A., Sandler, D.P. and Langston, J.W. (2011) Rotenone, Paraquat and Parkinson's Disease. Environmental Health Perspectives, 119, 866-872. http://dx.doi.org/10.1289/ehp.1002839

[55] Doull, J. (1989) Pesticide Carcinogenicity: Introduction and Background. In: Ragsdale, N. and Menzer, R.E., Eds., Carcinogenicity and Pesticides: Principles, Issues and Relationships, American Chemical Society, Washington, DC, 1-5. http://dx.doi.org/10.1021/bk-1989-0414.ch001

[56] Malato, S., Blaneo, J. and Richter, C. (1999) Solar Photocatalytic Mineralization of Commercial Pesticides: Methamidophos. Chemosphere, 38, 1145-1156. http://dx.doi.org/10.1016/S0045-6535(98)00364-6

[57] Foster, L.J., Kwan, B.H. and Vancov, T. (2004) Microbial Degradation of Organophosphate Pesticide, Ethion. FEMS Microbiology Letters, 240, 49-53. http://dx.doi.org/10.1016/j.femsle.2004.09.010

[58] Muhamad, S.G. (2010) Kinetic Studies of Catalytic Photodegradation of Chlorpyrifos Insecticide in Various Natural Waters. Arabian Journal of Chemistry, 3, 127-133. http://dx.doi.org/10.1016/j.arabjc.2010.02.009

[59] Abdennouri, M., Galadi, A., Barka, N., Baâlala, M., Nohair, K., Elkrati, M., Sadiq, M. and Bensitel, M. (2010) Synthesis, Characterization and Photocatalytic Activity by Para-Chlorotoluene Photooxidation of Tin Oxide Films Deposited on Pyrex Glass Substrates. Physical Chemistry News, 54, 126-130.

[60] Barka, N., Qourzal, S., Assabbane, A., Nounah, A. and Aît-Ichou, Y. (2010) Photocatalytic Degradation of an Azo Reactive Dye, Reactive Yellow 84, in Water Using an Industrial Titanium Dioxide Coated Media. Arabian Journal of Chemistry, 3, 279-283. http://dx.doi.org/10.1016/j.arabjc.2010.06.016

[61] Konstantinou, I.K. and Albanis, A.T. (2002) Photocatalytic Transformation of Pesticides in Aqueous Titanium Dioxide Suspensions Using Artificial and Solar Light: Intermediates and Degradation Pathways. Applied Catalysis B: Environmental, 1310, 1-17.

[62] Pelizzetti, E., Maurino, V., Minero, C., Carlin, V., Pramauro, E., Zerbinati, O. and Tosato, M.L. (1990) Photocatalytic Degradation of Atrazine and Other S-Triazine Herbicides. Environmental Science and Technology, 24, 1559-1565. http://dx.doi.org/10.1021/es00080a016

[63] Lhomme, L., Brosillon, S. and Wolbert, D. (2008) Photocatalytic Degradation of Pesticides in Pure Water and a Commercial Agricultural Solution on $\mathrm{TiO}_{2}$ Coated Media. Chemosphere, 70, 381-386. http://dx.doi.org/10.1016/j.chemosphere.2007.07.004

[64] Pichat, P., Vannier, S., Dussaud, J. and Rubis, J.P. (2004) Field Solar Photocatalytic Purification of Pesticides-Containing Rinse Waters from Tractor Cisterns Used for Grape Vine Treatment. Solar Energy, 77, 533-542. http://dx.doi.org/10.1016/j.solener.2004.03.023

[65] Dionysiou, D.D., Khodadoust, A.P., Kern, A.M., Suidan, M.T., Baudin, I. and Laine, J.M. (2000) Continuous-Mode Photocatalytic Degradation of Chlorinated Phenols and Pesticides in Water Using a Bench-Scale $\mathrm{TiO}_{2}$ Rotating Disk Reactor. Applied Catalysis B: Environmental, 24, 139-155. http://dx.doi.org/10.1016/S0926-3373(99)00103-4

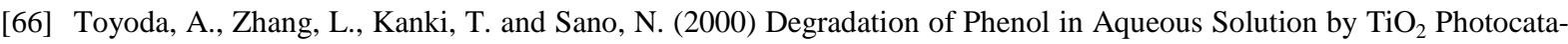
lyst Coated Rotating-Drum Reactor. Journal of Chemical Engineering of Japan, 33, 188-191. http://dx.doi.org/10.1252/jcej.33.188

[67] Molinari, R., Palmisano, L., Drioli, E. and Schiavello, M. (2002) Studies on Various Reactor Configurations for Coupling Photocatalysis and Membrane Processes in Water Purification. Journal of Membrane Science, 206, 399-415. http://dx.doi.org/10.1016/S0376-7388(01)00785-2

[68] Zapata, A., Oller, I., Sirtory, C., Rodríguez, A., Sánchez Pérez, J.A., López, A., Mezcua, M. and Malato, S. (2010) Decontamination of Industrial Waste Water, Containing Pesticides by Combining Large Scale Homogeneous Solar Photocatalysis and Biological Treatment. Chemical Engineering Journal, 160, 447-456. http://dx.doi.org/10.1016/j.cej.2010.03.042

[69] Araña, J., Garriga i Cabo, C., Fernández-Rodríguez, C., Herrera Melián, J.A., Ortega Méndez, J.A., Doña Rodríguez, J.M. and Pérez Peña, J. (2008) Combining $\mathrm{TiO}_{2}-$ Photocatalysis and Wetland Reactors for the Efficient Treatment of 
Pesticides. Chemosphere, 71, 788-794. http://dx.doi.org/10.1016/j.chemosphere.2007.10.008

[70] Navarro, S., Fenoll, J., Vela, N., Ruiz, E. and Navarro, G. (2009) Photocatalytic Degradation of Eight Pesticides in Leaching Water by Use of ZnO under Natural Sunlight. Journal of Hazardous Materials, 172, 1303-1310. http://dx.doi.org/10.1016/j.jhazmat.2009.07.137

[71] Liu, G.H., Zhu, Y.F., Zhang, X.R. and Xu, B.Q. (2002) Chemiluminescence Determination of Chlorinated Volatile Organic Compounds by Conversion on Nanometer $\mathrm{TiO}_{2}$. Analytical Chemistry, 74, 6279-6284. http://dx.doi.org/10.1021/ac025882u

[72] Echavia, G.R.M., Matzusawa, F. and Negishi, N. (2009) Photocatalytic Degradation of Organophosphate and Phosphonoglycine Pesticides Using $\mathrm{TiO}_{2}$ Immobilized on Silica Gel. Chemosphere, 76, 595-600. http://dx.doi.org/10.1016/j.chemosphere.2009.04.055

[73] Choi, W., Hong, S.J., Chang, Y.S. and Cho, Y. (2000) Photocatalytic Degradation of Polychlorinated Dibenzo-p-Dioxin on $\mathrm{TiO}_{2}$ Film under UV and Solar Light Irradiation. Environmental Science and Technology, 34, 4810-4815. http://dx.doi.org/10.1021/es0011461

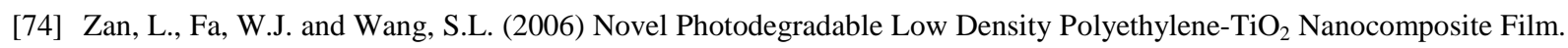
Environmental Science \& Technology, 40, 1681-1685. http://dx.doi.org/10.1021/es051173x

[75] Yu, B., Zeng, J., Gong, L., Zhang, M., Zhang, L. and Chen, X. (2007) Investigation of the Photocatalytic Degradation of Organochlorine Pesticides on A Nano- $\mathrm{TiO}_{2}$ Coated Film. Talanta, 72, 1667-1674. http://dx.doi.org/10.1016/j.talanta.2007.03.013

[76] Herrmann, J.M., Guillard, C., Arguello, M., Agüera, A., Tejedor, A., Piedra, L. and Fernández-Alba, A. (1999) Photocatalytic Degradation of Pesticide Pirimiphos-Methyl: Determination of the Reaction Pathway and Identification of Intermediate Products by Various Analytical Methods. Catalysis Today, 54, 353-367. http://dx.doi.org/10.1016/S0920-5861(99)00196-0

[77] Adesina, S. (2004) Industrial Exploitation of Photocatalysis: Progress, Perspectives and Prospects. Catalysis Surveys from Asia, 8, 265-273. http://dx.doi.org/10.1007/s10563-004-9117-0

[78] Mukherjee, P.S. and Ray, A.K. (1999) Major Challenges in the Design of a Large Scale Photocatalytic Reactor for Water Treatment. Chemical Engineering \& Technology, 22, 253-260. http://dx.doi.org/10.1002/(SICI)1521-4125(199903)22:3<253::AID-CEAT253>3.0.CO;2-X

[79] Moctezuma, E., Leyva, E., Palestino, G. and Lasa, H.D. (2007) Photocatalytic Degradation of Methyl Parathion: Reaction Pathways and Intermediate Reaction Products. Journal of Photochemistry and Photobiology A: Chemistry, 186, 71-84. http://dx.doi.org/10.1016/j.jphotochem.2006.07.014

[80] Legrini, O., Oliveros, E. and Braun, A.M. (1993) Photochemical Process for Water Treatment. Chemical Reviews, 93, 671-698. http://dx.doi.org/10.1021/cr00018a003

[81] Ruiz, M.J., López Jaramillo, L., Redondo, M.J. and Font, G. (1997) Toxicity Assessment of Pesticides Using the Microtox Test Application to Environmental Samples. Bulletin of Environmental Contamination and Toxicology, 59, 619625. http://dx.doi.org/10.1007/s001289900524

[82] Tapp, J.F., Hult, S.M. and Wharfe, J.R. (1996) Toxic Impact of Wastes on the Aquatic Environment. Royal Society of Chemistry, London.

[83] Bahnemann, D., Cunningham, J., Fox, M.A., Pelizzetti, E., Pichat, P. and Serpone, N.I.N. (1994) Photocatalytic treatment of waters. In: Helz, G.R., Zepp, R.G. and Crosby, D.G., Eds., Aquatic and Surface Photochemistry, Lewis Publishers, Boca Raton, FL, 261.

[84] Ollis, D.F., Pelizzetti, E. and Serpone, N. (1991) Photocatalyzed Destruction of Water Contaminants. Environmental Science and Technology, 25, 1523-1529. http://dx.doi.org/10.1021/es00021a001

[85] Mills, A. and Le Hunte, S. (1997) An Overview of Semiconductor Photocatalysis. Journal of Photochemistry and Photobiology A: Chemistry, 108, 1-35. http://dx.doi.org/10.1016/S1010-6030(97)00118-4

[86] Hansen, L.G. (1998) Stepping Backward to Improve Assessment of PCB Congener Toxicities. Environmental Health Perspectives, 106, 171-189. http://dx.doi.org/10.1289/ehp.98106s1171

[87] Jegou, B. (1998) S14/L1—An Introduction to Endocrine Disruption Science. Toxicology Letters, 95, 16-17. http://dx.doi.org/10.1016/S0378-4274(98)80065-9

[88] Roepke, T.A., Snyder, M.J. and Cherr, G.N. (2005) Estradiol and Endocrine Disrupting Compounds Adversely Affect Development of Sea Urchin Embryos at Environmentally Relevant Concentrations. Aquatic Toxicology, 71, 155-173. http://dx.doi.org/10.1016/j.aquatox.2004.11.003

[89] Rhind, S.M. (2005) Are Endocrine Disrupting Compounds a Threat to Farm Animal Health, Welfare and Productivity? Reproduction in Domestic Animals, 40, 282-290. http://dx.doi.org/10.1111/j.1439-0531.2005.00594.X

[90] Spano, M., Toft, G., Hagmar, L., Eleuteri, P., Rescia, M., Rignell-Hydbom, A., Tyrkiel, E., Zvyezday, V., Bonde, J.P. 
and INUENDO (2005) Exposure to PCB and P, P'-DDE in European and Inuit Populations: Impact on Human Sperm Chromatin Integrity. Human Reproduction, 20, 3488-3499. http://dx.doi.org/10.1093/humrep/dei297

[91] Kümmerer, K. (2001) Drugs in the Environment: Emission of Drugs, Diagnostic Aids and Disinfectants into Wastewater by Hospitals in Relation to Other Sources-A Review. Chemosphere, 45, 957-969. http://dx.doi.org/10.1016/S0045-6535(01)00144-8

[92] Wise, R., Hart, T., Cars, O., Streulens, M., Helmuth, R., Huovinen, P. and Sprenger, M. (1998) Antimicrobial Resistance: Is a Major Threat to Public Health. British Medical Journal, 317, 609-610. http://dx.doi.org/10.1136/bmj.317.7159.609

[93] Dokianakis, S.N., Kornaros, M.E. and Lyberatos, G. (2004) On the Effect of Pharmaceuticals on Bacterial Nitrite Oxidation. Water Science and Technology, 50, 341-346.

[94] Fountoulakis, M., Drillia, P., Stamatelatou, K. and Lyberatos, G. (2004) Toxic Effect of Pharmaceuticals on Methanogenesis. Water Science and Technology, 50, 335-340.

[95] Eljarrat, E. and Barcelo, D. (2003) Priority Lists for Persistent Organic Pollutants and Emerging Contaminants Based on Their Relative Toxic Potency in Environmental Samples. TrAC Trends in Analytical Chemistry, 22, 655-665. http://dx.doi.org/10.1016/S0165-9936(03)01001-X

[96] Kolpin, D.W., Furlong, E.T., Meyer, M.T., Thurman, E.M., Zaugg, S.D., Barber, L.B. and Buxton, H.T. (2002) Pharmaceuticals, Hormones, and Other Organic Wastewater Contaminants in US Streams, 1999-2000: A National Reconnaissance. Environmental Science and Technology, 36, 1202-1211. http://dx.doi.org/10.1021/es011055j

[97] Huber, M.M., Canonica, S., Park, G.Y. and Von Gunten, U. (2003) Oxidation of Pharmaceuticals during Ozonation and Advanced Oxidation Processes. Environmental Science and Technology, 37, 1016-1024. http://dx.doi.org/10.1021/es025896h

[98] Hirsch, R., Ternes, T., Haberer, K. and Kratz, K.L. (1999) Occurrence of Antibiotics in the Aquatic Environment. Science of the Total Environment, 225, 109-118. http://dx.doi.org/10.1016/S0048-9697(98)00337-4

[99] Colborn, T., Dumanoski, D. and Myers, J.P. (1996) Our Stolen Future: Are We Threatening Our Fertility, Intelligence, and Survival? A Scientific Detective Story. Dutton, New York.

[100] Yoon, Y., Westerhoff, P., Snyder, S.A. and Wert, E.C. (2006) Nanofiltration and Ultrafiltration of Endocrine Disrupting Compounds, Pharmaceuticals and Personal Care Products. Journal of Membrane Science, 270, 88-100. http://dx.doi.org/10.1016/j.memsci.2005.06.045

[101] Wintgens, T., Gallenkemper, M. and Melin, T. (2004) Removal of Endocrine Disrupting Compounds with Membrane Processes in Wastewater Treatment and Reuse. Water Science and Technology, 50, 1-8.

[102] Petrovic, M., Gonzalez, S. and Barcelo, D. (2003) Analysis and Removal of Emerging Contaminants in Wastewater and Drinking Water. TrAC Trends in Analytical Chemistry, 22, 685-696. http://dx.doi.org/10.1016/S0165-9936(03)01105-1

[103] Zhou, H., Nusier, O.K. and Smith, D.W. (2002) Advanced Technologies in Water and Wastewater Treatment. Journal of Environmental Engineering and Science, 1, 247-264. http://dx.doi.org/10.1139/s02-020

[104] Radjenovic, J., Petrovic, M. and Barceló, D. (2007) Analysis of Pharmaceuticals in Wastewater and Removal Using a Membrane Bioreactor. Analytical and Bioanalytical Chemistry, 387, 1365-1377. http://dx.doi.org/10.1007/s00216-006-0883-6

[105] Radjenovic, J., Petrovic, M. and Barcelo, D. (2009) Fate and Distribution of Pharmaceuticals in Wastewater and Sewage Sludge of the Conventional Activated Sludge (CAS) and Advanced Membrane Bioreactor (MBR) Treatment. Water Research, 43, 831-841. http://dx.doi.org/10.1016/j.watres.2008.11.043

[106] Kimura, K., Hara, H. and Watanabe, Y. (2005) Removal of Pharmaceutical Compounds by Submerged Membrane Bioreactors (Mbrs). Desalination, 178, 135-140. http://dx.doi.org/10.1016/j.desal.2004.11.033

[107] Weber, S., Gallenkemper, M., Melin, T., Dott, W. and Hollender, J. (2004) Efficiency of Nanofiltration for the Elimination of Steroids from Water. Water Science and Technology, 50, 9-14.

[108] Rizzo, L., Meric, S., Guida, M., Kassinos, D. and Belgiorno, V. (2009) Heterogeneous Photocatalytic Degradation Kinetics and Detoxification of an Urban Wastewater Treatment Plant Effluent Contaminated with Pharmaceuticals. Water Research, 43, 4070-4078. http://dx.doi.org/10.1016/j.watres.2009.06.046

[109] Benotti, M.J., Stanford, B.D., Wert, E.C. and Snyder, S.A. (2009) Evaluation of a Photocatalytic Reactor Membrane Pilot System for the Removal of Pharmaceuticals and Endocrine Disrupting Compounds from Water. Water Research, 43, 1513-1522. http://dx.doi.org/10.1016/j.watres.2008.12.049

[110] Laera, G., Chong, M.N., Jin, B. and Lopez, A. (2011) An Integrated MBR-TiO 2 Photocatalysis Process for the Removal of Carbamazepine from Simulated Pharmaceutical Industrial Effluent. Bioresource Technology, 102, 7012-7015. http://dx.doi.org/10.1016/j.biortech.2011.04.056 
[111] Yahiat, S., Fourcade, F., Brosillon, S. and Amrane, A. (2011) Removal of Antibiotics by an Integrated Process Coupling Photocatalysis and Biological Treatment-Case of Tetracycline and Tylosin. International Biodeterioration \& Biodegradation, 65, 997-1003. http://dx.doi.org/10.1016/j.ibiod.2011.07.009

[112] Kabra, K., Chaudhary, R. and Sawhney, R.L. (2004) Treatment of Hazardous Organic and Inorganic Compounds through Aqueous-Phase Photocatalysis: A Review. Industrial \& Engineering Chemistry Research, 43, 7683-7696. http://dx.doi.org/10.1021/ie0498551

[113] Giraldo, A.L., Peñuela, G.A., Torres-Palma, R.A., Pino, N.J., Palominos, R.A. and Mansilla, H.D. (2010) Degradation of the Antibiotic Oxolinic Acid by Photocatalysis, with $\mathrm{TiO}_{2}$ in Suspension. Water Research, 44, 5158-5167. http://dx.doi.org/10.1016/j.watres.2010.05.011

[114] Maroga Mboula, V., Héquet, V., Gru, Y., Colin, R. and Andrès, Y. (2012) Assessment of the Efficiency of Photocatalysis on Tetracycline Biodegradation. Journal of Hazardous Materials, 209-210, 355-364. http://dx.doi.org/10.1016/j.jhazmat.2012.01.032

[115] Kümmerer, K., Al-Ahmad, A. and Mersch-Sundermann, V. (2000) Biodegradability of Some Antibiotics, Elimination of the Genotoxicity and Affection of Wastewater Bacteria in a Simple Test. Chemosphere, 40, 701-710. http://dx.doi.org/10.1016/S0045-6535(99)00439-7

[116] Esiobu, N., Armenta, L. and Ike, J. (2002) Antibiotic Resistance in Soil and Water Environments. International Journal of Environmental Health Research, 12, 133-144. http://dx.doi.org/10.1080/09603120220129292

[117] Challis, J.K., Hanson, M.L., Friesenc, K.J. and Wong, C.S. (2014) A Critical Assessment of the Photodegradation of Pharmaceuticals in Aquatic Environments: Defining Our Current Understanding and Identifying Knowledge Gaps. Environmental Science. Processes and Impacts, 16, 672-696.

[118] Palominos, R.A., Mondaca, M.A., Giraldo, A., Peñnuela, G., Pérez-Moya, M. and Mansilla, H.D. (2009) Photocatalytic Oxidation of the Antibiotic Tetracycline on $\mathrm{TiO}_{2}$ and $\mathrm{ZnO}$ Suspensions. Catalysis Today, 144, 100-105. http://dx.doi.org/10.1016/j.cattod.2008.12.031

[119] Reyes, C., Fernández, J., Freer, J., Mondaca, M.A., Zaror, C., Malato, S. and Mansilla, H.D. (2006) Degradation and Inactivation of Tetracycline by $\mathrm{TiO}_{2}$ Photocatalysis. Journal of Photochemistry and Photobiology A, 184, 141-146. http://dx.doi.org/10.1016/j.jphotochem.2006.04.007

[120] Zhang, J., Fu, D. and Wu, J. (2012) Photodegradation of Norfloxacin in Aqueous Solution Containing Algae. Journal of Environmental Sciences, 24, 743-749. http://dx.doi.org/10.1016/S1001-0742(11)60814-0

[121] Ratola, N., Cincinelli, A., Alves, A. and Katsoyiannis, A. (2012) Occurrence of Organic Microcontaminants in the Wastewater Treatment Process. A Mini Review. Journal of Hazardous Materials, 239-240, 1-18.

[122] Rizzo, L., Meric, S., Kassinos, D., Guida, M., Russo, F. and Belgiorno, V. (2009) Degradation of Diclofenac by $\mathrm{TiO}_{2}$ Photocatalysis: UV Absorbance Kinetics and Process Evaluation through a Set of Toxicity Bioassays. Water Research, 43, 979-988. http://dx.doi.org/10.1016/j.watres.2008.11.040

[123] Chong, M.N. and Jin, B. (2012) Photocatalytic Treatment of High Concentration Carbamazepine in Synthetic Hospital Wastewater. Journal of Hazardous Materials, 199-200, 135-142.

[124] Nasuhoglu, D., Berk, D. and Yargeau, V. (2012) Photocatalytic Removal of $17 \alpha$-Ethinylestradiol (EE2) and Levonorgestrel (LNG) from Contraceptive Pill Manufacturing Plant Wastewater under UVC Radiation. Chemical Engineering Journal, 185-186, 52-60.

[125] Coleman, H.M., Eggins, B.R., Byrne, J.A., Palmer, F.L. and King, E. (2000) Photocatalytic Degradation of 17- $\beta$-Oestradiol on Immobilised $\mathrm{TiO}_{2}$. Applied Catalysis B: Environmental, 24, L1-L5. http://dx.doi.org/10.1016/S0926-3373(99)00091-0

[126] Coleman, H.M., Routledge, E.J., Sumpter, J.P., Eggins, B.R. and Byrne, J.A. (2004) Rapid Loss of Estrogenicity of Steroid Estrogens by UVA Photolysis and Photocatalysis over an Immobilised Titanium Dioxide Catalyst. Water Research, 38, 3233-3240. http://dx.doi.org/10.1016/j.watres.2004.04.021

[127] Coleman, H.M., Abdullah, M.I., Eggins, B.R. and Palmer, F.L. (2005) Photocatalytic Degradation of 17 $\beta$-Oestradiol, Oestriol and $17 \alpha$-Ethynyloestradiol in Water Monitored Using Fluorescence Spectroscopy. Applied Catalysis B: Environmental, 55, 23-30. http://dx.doi.org/10.1016/j.apcatb.2004.07.004

[128] Karpova, T., Preis, S. and Kallas, J. (2007) Selective Photocatalytic Oxidation of Steroid Estrogens in Water Treatment: Urea as Co-Pollutant. Journal of Hazardous Materials, 146, 465-471. http://dx.doi.org/10.1016/j.jhazmat.2007.04.047

[129] Karpova, T., Preis, S., Kallas, J. and Torres, A.L.B. (2007) Selective Photocatalytic Oxidation of Steroid Estrogens in Presence of Saccharose and Ethanol as Copollutants. Environmental Chemistry Letters, 5, 219-224. http://dx.doi.org/10.1007/s10311-007-0103-4

[130] Mai, J., Sun, W., Xiong, L., Liu, Y. and Ni, J. (2008) Titanium Dioxide Mediated Photocatalytic Degradation of 17 $\beta$-Estradiol in Aqueous Solution. Chemosphere, 73, 600-606. http://dx.doi.org/10.1016/j.chemosphere.2008.05.073

[131] Nakashima, T., Ohko, Y., Tryk, D.A. and Fujishima, A. (2002) Decomposition of Endocrine-Disrupting Chemicals in 
Water by Use of $\mathrm{TiO}_{2}$ Photocatalysts Immobilized on Polytetrafluoroethylene Mesh Sheets. Journal of Photochemistry and Photobiology A: Chemistry, 151, 207-212. http://dx.doi.org/10.1016/S1010-6030(02)00139-9

[132] Nakashima, T., Ohko, Y., Kubota, Y. and Fujishima, A. (2003) Photocatalytic Decomposition of Estrogens in Aquatic Environment by Reciprocating Immersion of $\mathrm{TiO}_{2}$-Modified Polytetrafluoroethylene Mesh Sheets. Journal of Photochemistry and Photobiology A: Chemistry, 160, 115-120. http://dx.doi.org/10.1016/S1010-6030(03)00229-6

[133] Ohko, Y., Iuchi, K.I., Niwa, C., Tatsuma, T., Nakashima, T., Iguchi, T., Kubota, Y. and Fujishima, A. (2002) 17 -Estradiol Degradation by $\mathrm{TiO}_{2}$ Photocatalysis as a Means of Reducing Estrogenic Activity. Environmental Science \& Technology, 36, 4175-4181. http://dx.doi.org/10.1021/es011500a

[134] Zhang, Y., Zhou, J.L. and Ning, B. (2007) Photodegradation of Estrone and 17 $\beta$-Estradiol in Water. Water Research, 41, 19-26. http://dx.doi.org/10.1016/j.watres.2006.09.020

[135] Zhang, Y. and Zhou, J.L. (2008) Occurrence and Removal of Endocrine Disrupting Chemicals in Wastewater. Chemosphere, 73, 848-853. http://dx.doi.org/10.1016/j.chemosphere.2008.06.001

[136] Puma, G.L., Puddu, V., Tsang, H.K., Gora, A. and Toepfer, B. (2010) Photocatalytic Oxidation of Multicomponent Mixtures of Estrogens (Estrone (E1), 17 $\beta$-Estradiol (E2), 17 $\alpha$-Ethynylestradiol (EE2) and Estriol (E3) under UVA and UVC Radiation: Photon Absorption, Quantum Yields and Rate Constants Independent of Photon Absorption. Applied Catalysis B: Environmental, 99, 388-397. http://dx.doi.org/10.1016/j.apcatb.2010.05.015

[137] Silva, C.P., Otero, M. and Esteves, V. (2012) Processes for the Elimination of Estrogenic Steroid Hormones from Water: A Review. Environmental Pollution, 165, 38-58. http://dx.doi.org/10.1016/j.envpol.2012.02.002

[138] Chiang, K., Lim, T.M., Tsen, L. and Lee, C.C. (2004) Photocatalytic Degradation and Mineralization of Bisphenol A by $\mathrm{TiO}_{2}$ and Platinized $\mathrm{TiO}_{2}$. Applied Catalysis A: General, 261, 225-237. http://dx.doi.org/10.1016/j.apcata.2003.11.004

[139] Ohko, Y., Ando, I., Niwa, C., Tatsuma, T., Yamamura, T., Nakashima, T., Kubota, Y. and Fujishima, A. (2001) Degradation of Bisphenol A in Water by $\mathrm{TiO}_{2}$ Photocatalyst. Environmental Science \& Technology, 35, 2365-2368. http://dx.doi.org/10.1021/es001757t

[140] Wang, C., Zhang, H., Li, F. and Zhu, L. (2010) Degradation and Mineralization of Bisphenol A by Mesoporous $\mathrm{Bi}_{2} \mathrm{WO}_{6}$ under Simulated Solar Light Irradiation. Environmental Science \& Technology, 44, 6843-6848. http://dx.doi.org/10.1021/es101890w

[141] Wang, C.Y., Zhu, L.Y., Wei, M.C., Chen, P. and Shan, G.Q. (2012) Photolytic Reaction Mechanism and Impacts of Coexisting Substances on Photodegradation of Bisphenol A by $\mathrm{Bi}_{2} \mathrm{WO}_{6}$ in Water. Water Research, 46, 845-853. http://dx.doi.org/10.1016/j.watres.2011.11.057

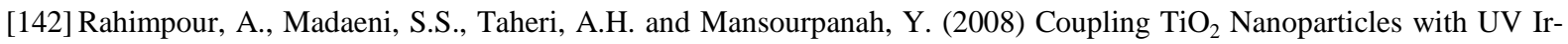
radiation for Modification of Polyethersulfone Ultrafiltration Membranes. Journal of Membrane Science, 313, 158-169. http://dx.doi.org/10.1016/j.memsci.2007.12.075

[143] Li, J.F., Xu, Z.L., Yang, H., Yu, L.Y. and Liu, M. (2009) Effect of $\mathrm{TiO}_{2}$ Nanoparticles on the Surface Morphology and Performance of Microporous PES Membrane. Applied Surface Science, 255, 4725-4732. http://dx.doi.org/10.1016/j.apsusc.2008.07.139

[144] Rahimpour, A., Madaeni, S.S., Jahanshahi, M., Mansourpanah, Y. and Mortazavian, N. (2009) Development of High Performance Nano-Porous Polyethersulfone Ultrafiltration Membranes with Hydrophilic Surface and Superior Antifouling Properties. Applied Surface Science, 255, 9166-9173. http://dx.doi.org/10.1016/j.apsusc.2009.06.123

[145] Elmolla, E.S. and Chaudhuri, M. (2011) The Feasibility of Using Combined $\mathrm{TiO}_{2}$ Photocatalysis-SBR Process for Antibiotic Wastewater Treatment. Desalination, 272, 218-224.

[146] Chong, M.N., Jin, B., Laera, G. and Saint, C.P. (2011) Evaluating the Photodegradation of Carbamazepine in a Sequential Batch Photoreactor System: Impacts of Effluent Organic Matter and Inorganic Ions. Chemical Engineering Journal, 174, 595-602. http://dx.doi.org/10.1016/j.cej.2011.09.065

[147] Mozia, S. (2010) Photocatalytic Membrane Reactors (PMRs) in Water and Wastewater Treatment. A Review. Separation and Purification Technology, 73, 71-79. http://dx.doi.org/10.1016/j.seppur.2010.03.021

[148] Das, R., Sarkar, S., Chakraborty, S., Choi, H. and Bhattacharjee, C. (2014) Remediation of Antiseptic Components in Wastewater by Photocatalysis Using $\mathrm{TiO}_{2}$ Nanoparticles. Industrial and Engineering Chemistry Research, 53, 30123020. http://dx.doi.org/10.1021/ie403817z

[149] Hwang, K.J., Lee, J.W., Shim, W.G., Jang, H.D., Lee, S.I. and Yoo, S.J. (2012) Adsorption and Photocatalysis of Nanocrystalline $\mathrm{TiO}_{2}$ Particles Prepared by Sol-Gel Method for Methylene Blue Degradation. Advanced Powder Technology, 23, 414-418. http://dx.doi.org/10.1016/j.apt.2011.05.010

[150] Byrappa, K., Subramani, A.K., Ananda, S., Lokanatha, K.M. and Dinesh, R. (2006) Photocatalytic Degradation of Rhodamine B Dye Using Hydrothermally Synthesized ZnO. Bulletin of Material Science, 29, 433-438. http://dx.doi.org/10.1007/BF02914073 
[151] Sanlaville, Y., Guittonneau, S., Mansour, M., Feicht, E.A., Meallier, P. and Kettrup, A. (1996) Photosensitized Degradation of Terbuthylazine in Water. Chemosphere, 33, 353-362. http://dx.doi.org/10.1016/0045-6535(96)00176-2

[152] Peris, C.E., Terol, J., Mauri, A.R., de la Guardia, M. and Pramauro, E. (1993) Continuous Flow Photocatalytic Degradation of Carbaryl in Aqueous Medium. Journal of Environmental Science and Health B, 28, 431-445. http://dx.doi.org/10.1080/03601239309372834

[153] Pramauro, E., Prevot, A.B., Vincenti, M. and Brizzolesi, G. (1997) Photocatalytic Degradation of Carbaryl in Aqueous Solution Containing $\mathrm{TiO}_{2}$ Suspension. Environmental Science and Technology, 31, 3126-3131. http://dx.doi.org/10.1021/es970072z

[154] Rabindranathan, S., Devipriya, S. and Yesodharan, S. (2003) Photocatalytic Degradation of Phosphamidon on Semiconductor Oxides. Journal of Hazardous Materials, 102, 217-229. http://dx.doi.org/10.1016/S0304-3894(03)00167-5

[155] Zaleska, A., Hupka, J., Wiergowski, M. and Bizuik, M. (2000) Photocatalytic Degradation of Lindane, P,P'-DDT and Methoxychlor in an Aqueous Environment. Journal Photochemistry and Photobiology A: Chemistry, 135, $213-220$. http://dx.doi.org/10.1016/S1010-6030(00)00296-3

[156] Zhu, X.D., Wang, Y.J., Sun, R.J. and Zhou, D.M. (2013) Photocatalytic Degradation of Tetracycline in Aqueous Solution by Nanosized $\mathrm{TiO}_{2}$. Chemosphere, 92, 925-932. http://dx.doi.org/10.1016/j.chemosphere.2013.02.066

[157] Tassalit, D. (2011) Photocatalytic Deterioration of Tylosin in an Aqueous Suspension Using UV/TiO 2 . Science of Advanced Materials, 3, 939-943.

[158] Parra, S., Stanca, S.E., Guasaquillo, I. and Thampi, K.R. (2004) Photocatalytic Degradation of Atrazine Using Suspended and Supported $\mathrm{TiO}_{2}$. Applied Catalysis B: Environmental, 51, 107-116.

http://dx.doi.org/10.1016/j.apcatb.2004.01.021 